\title{
Aging as Planned Obsolescence: The Case of Alzheimer's Disease
}

\author{
Mario D Garrett* \\ San Diego State University, USA
}

*Corresponding author: Mario D Garrett, San Diego State University, USA.

Received Date: June 11, 2019

Published Date: June 17, 2019

\section{Short Communication}

Psychologically it is easy to see how attractive it is to define old age as a disease [1,2]. We can then explain Alzheimer's disease, the fifth killer in the U.S. as simply accelerated aging. A faulty switch that starts a cascade of misfolded proteins that congeal in the brain forming plaques and tangles [3] that ultimate lead to Alzheimer's disease [4]. But this scenario only holds true in our mind. Observations contradict these assumptions. Aging is not just a switch that accelerates diminished capacities, and plaques and tangles do not solely cause Alzheimer's disease. Unlike with younger people, older adults have complex neurological problems. Singling out Alzheimer's disease and trying to show neurological correlates are doomed to failure with older adults since they have so many other pathologies [5]. That is why the most recent U.S. National Institute on Aging directive-to define Alzheimer's purely on biological indicators of the plaques and tangles-is doomed to failure with older people [6]. The correlation of these biomarkers with Alzheimer's disease declines as people get older [7]. There are many other neuropathologists interfering with the brain at older age [8,9]. Although we cannot explain Alzheimer's disease as caused by simple malfunction of two misfolded protein, we can also not assign the cause to old age, even though both are correlates of the disease. As Sherwin Nuland portrayed, diseases in older age are choreographed disorder that climaxes in death [10].

In 2011 Heido Braak [11] autopsied more than two thousand brains from 1 to 100 years of age. They found that nearly all had both plaques and tangles. But what was interesting was that they found that these misfolded proteins first show up in the brainstem at much earlier age [12]. The seeds of what we call aging have a lifetime of gestation. We are programmed to age as part of planned obsolescence. When Alzheimer's disease hits early, we notice it because it is not anticipated that early. This is the observation also made by Alois Alzheimer. He only noticed it because it was too early 'Senile dementia was never considered because of the onset at the age of 54 [13], otherwise it was the same as senile (old age) dementia there are cases of senile dementia which do not differ from these presenile cases with respect to the severity of disease process.' [14].

Planned obsolescence is not a disease it is our natural state. This explains why among older people we never see Alzheimer's disease in isolation, and we see it together with other dementias Creutzfeldt Jakob disease [15]; Lewy Body dementia [16] and another neuropathologist Jentoft et al., Sonnen et al. At the end all the engineering in planned obsolescence converge so that only 0.01 percent of older patients have a diagnosis of dementia with no co-morbid conditions [17]. Planned obsolescence differs from a disease. With planned obsolescence you have to address the engineering of nature rather than its mishap as in a disease [18]. Perhaps that is the barrier for moving ahead in studying Alzheimer's disease, it is easier to blame nature rather than to understand it.

\section{Acknowledgement}

None.

\section{Conflict of interest}

No conflict of interest.

\section{References}

1. Bulterijs S, Hull R S, Björk VC, Roy AG (2015) It is time to classify biological aging as a disease. Front Genet 6: 205.

2. Caplan A (2017) How Can Aging Be Thought of as Anything Other Than a Disease? Handbook of the Philosophy of Medicine 233-240

3. Hardy JA, Higgins GA (1992) Alzheimer's disease: the amyloid cascade hypothesis. Science 256(5054): 184-186.

4. Jack CR, Albert MS, Knopman DS, Mc Khann GM, Sperling RA, et al, (2011) Introduction to the recommendations from the National Institute on Aging-Alzheimer's Association workgroups on diagnostic guidelines for Alzheimer's disease. Alzheimers Dement 7(3): 257-262. 
5. Sonnen JA, Larson EB, Crane PK, Haneuse S, Li G, et al. (2007) Pathological correlates of dementia in a longitudinal, population-based sample of aging. Ann Neurol 62(4): 406-413.

6. Jack CR, Bennett DA, Blennow K, Carrillo MC, Dunn B, et al. (2018) NIAAA Research Framework: Toward a biological definition of Alzheimer's disease. Alzheimers Dement 14(4): 535-562.

7. Savva GM, Wharton SB, Ince PG, Forster G, Matthews FE, et al. (2009). Age, neuropathology, and dementia. N Engl J Med 361(11): 1118.

8. Jellinger KA, Attems J (2015) Challenges of multimorbidity of the aging brain: a critical update. Journal of neural transmission 122(4): 505-521.

9. Jentoft M, Parisi J, Dickson D, Johnson K, Boeve B, et al. (2011) Neuropathologic findings in 32 nondemented elderly subjects (abs.). J Neuropathol Exp Neurol 70: 531.

10. Nuland SB (1995) How we die: Reflections on life's final chapter. Vintage.

11. Braak H, Braak E (1997) Frequency of stages of Alzheimer-related lesions in different age categories. Neurobiol Aging 18(4): 351-357.

12. Braak H, Thal DR, Ghebremedhin E, Del Tredici K (2011) Stages of the pathologic process in Alzheimer disease: age categories from 1 to 100 years. J Neuropathol Exp Neurol 70(11): 960-969.
13. Alzheimer A, In Bick K, Amaducci L (1912) The early story of Alzheimer's disease: translation of the historical papers by Alois Alzheimer, Oskar Fischer, Francesco Bonfiglio, Emil Kraepelin, and Gaetano Perusini. Padova, Liviana Press, Italy.

14. Whitehouse PJ, Maurer K, Ballenger JF (2000) Aging, culture, and the framing of Alzheimer disease. Concepts of Alzheimer disease: Biological, clinical and cultural.

15. Robinson JL, Corrada MM, Kovacs GG, Dominique M, Caswell C, et al. (2018) Non-Alzheimer's contributions to dementia and cognitive resilience in the 90+ Study. Acta Neuropathol 136(3): 377-388.

16. McKeith IG, T O Brien J, Ballard C (1999) Diagnosing dementia with Lewy bodies. The Lancet 354(9186): 1227-1228.

17. Sanderson M, Wang J, Davis DR, Lane MJ, Cornman CB, et al. (2002) Comorbidity associated with dementia. Am J Alzheimers Dis Other Demen 17(2):73-78.

18. Hayflick L (1985) Theories of biological aging. Experimental gerontology 20(3-4): 145-159. 